\title{
Study of environmental thermal variation in vineyards harvested by different curtain colors used as lateral closure
}

\author{
Estudo da variação térmica ambiental em galpões avícolas ocasionada por \\ diferentes cores de cortina utilizadas como fechamento lateral
}

\author{
Estudio de la variación térmica ambiental en galpones avículas ocasionada por \\ diferentes colores de cortina utilizados como cierre lateral
}

\author{
Helio Ávalo ${ }^{1}$ \\ Rodrigo Couto Santos ${ }^{1}$ \\ Marney Pascoli Cereda ${ }^{2}$ \\ Glaucia Almeida de Morais ${ }^{3}$
}

Recebido em 13/04/2018; revisado e aprovado em 21/06/2018 ; aceito em 28/06/2018

DOI: http://dx.doi.org/10.20435/inter.v20i4.1934

\begin{abstract}
The objective of this research was to evaluate the thermal influence of the white and blue colors of the sanitary curtain used as lateral closures in commercial broiler chickens, aiming at the welfare and environment suitable for the production of broilers. At the end of 42 days, the white curtain represented the best average surface temperature, between 27.40 and $35.5^{\circ}$, when evaluated without supplementary ventilation. It was also possible to conclude that the white color curtain was more efficient to maintain the well-being inside the aviary, especially in the sixth week of production, verified by infrared thermography.

Keywords: cutting poultry; thermal comfort; infra-red thermography.

Resumo: O objetivo desta pesquisa foi avaliar a influência térmica das cores branca e azul da cortina sanitária utilizadas como fechamentos laterais em galpão comercial de frangos de corte, visando ao bem-estar e ambiente adequado à produção de frangos de corte. Ao final de 42 dias, a cortina branca representou a melhor temperatura superficial média, entre 27,4 ㅇ C e 35,5 으, se avaliada sem ventilação complementar. Foi possível concluir também que a cortina de cor branca mostrou-se mais eficiente para manter o bemestar no interior do aviário, principalmente na sexta semana de produção, fato este verificado por meio de termografia infravermelha.
\end{abstract}

Palavras-chave: avicultura de corte; conforto térmico; termografia infravermelha.

Resumen: El objetivo de esta investigación fue evaluar la influencia térmica de los colores blanco y azul de la cortina sanitaria utilizadas como cerramientos laterales en galpón comercial de pollos de corte, visando el bienestar y ambiente adecuado a la producción de pollos de corte. Al final de 42 días la cortina blanca representó la mejor temperatura superficial media, entre 27,4 으 y 35,5으, si se evalúa sin ventilación complementaria. Se pudo concluir también que la cortina de color blanca se mostró más eficiente para mantener el bienestar en el interior del aviario, principalmente en la sexta semana de producción, hecho este verificado por medio de termografía infrarroja.

Palabras clave: avicultura de corte; confort térmico; termografía infrarroja.

\section{INTRODUCTION}

Brazilian poultry farming is a worldwide agricultural activity due to the low cost of production and adequate quality of the final product. At the global level, since 2,000 the volume of slaughtered chickens has registered positive variation each year and in 2016 the annual slaughter of chickens was 5.86 billion tons (BRAZILIAN ANIMAL PROTEIN ASSOCIATION [ABPA], 2017).

\footnotetext{
${ }^{1}$ Universidade Federal da Grande Dourados, UFGD, Dourados, Mato Grosso do Sul, Brasil.

${ }^{2}$ Universidade Católica Dom Bosco, UCDB, Campo Grande, Mato Grosso do Sul, Brasil.

${ }^{3}$ Universidade Estadual de Mato Grosso do Sul (UEMS), Unidade de Ivinhema, Ivinhema, Mato Grosso do Sul, Brasil.
} 
According to data collected from the Annual Report released by the Brazilian Animal Protein Association (ABPA), the Brazilian production of chicken meat totaled 13.146 million tons in 2015, a volume $3.58 \%$ higher than in 2014. Per capita consumption of chicken meat reached an average of $43.25 \mathrm{~kg}$ in 2015, a balance 1.1\% higher than that obtained in the previous year (ABPA, 2017).

In addition to the region of Rio Claro SP, one of the major Brazilian poles for breeding birds, other regions of the state stand out (RAMOS, 2016). In São Paulo production, production statistics for 2017 indicated an installed production capacity of 128.70 million head, $0.39 \%$ higher than the one in 2016, which is equivalent to $11.56 \%$ of the share and places the State in 4th place place in the national poultry ranking. The sector is represented by 1,141 aviaries and 490 integrated producers, who raise animals with subsidies from the poultry industry (integrated system) (IBGE - BRAZILIAN INSTITUTE OF GEOGRAPHY AND STATISTICS, 2017).

The development of this activity was due to scientific and technological advances in the areas of nutrition, management, health, genetics, veterinary products and, more recently, the thermal conditioning of the facilities, which turned the enterprise into an agro industrial complex responsible for 1.5 \% of Brazil's GDP (RODRIGUES et al., 2017).

The production environment is characterized by a set of physical, chemical, social and climatic elements that act simultaneously and exert influences on animals in a favorable or unfavorable way to the biological development, to the productive and reproductive performance of the birds (BAÊTA; SOUZA, 2010).

According to Baêta and Souza (2010), the width of the aviary has a great influence on the interior thermal conditioning and its cost, with a world trend of $12 \mathrm{~m}$ wide and $125 \mathrm{~m}$ long sheds with a view to optimizing the use of modern equipment. The minimum height of $3 \mathrm{~m}$ promotes the reduction of the thermal load of radiation accumulated in the shelter and in this case it varies depending on the natural ventilation.

In the production of broiler chicken, the increase in the ambient temperature can cause problems related to the thermal comfort and well being of the birds, since the productive performance depends, among other factors, on the reduction of the climatic effects on the animals. Therefore, the thermal comfort within the facilities is directly related to the heat produced by the animals, which, in turn, comes from the interaction between the solar radiation, heat exchanged by roofing materials, walls, floor or bed, and thermal or natural ventilation (SEKHAR, 2016).

According to Zhu (2017), these energy exchanges occur through four components, namely radiation, conduction, convection (sensitive exchanges) and evaporation (latent exchange). For birds the convection occurs by tachypnea, an important mechanism of thermal changes between the animal and the production environment.

For Rajaei-Sharifabadi (2017), heat losses in birds are controlled by altering blood flow in the body surface, or by the rate of evaporation in the respiratory tract. The increase in the surface temperature can act as a physiological response of the bird to inadequate housing conditions (CECCHIN et al., 2016), reflecting a perceptual change in the animal's comfort state. Infrared thermography can be used to evaluate this variation. Boccardi et al. (2016) suggest that the use of thermo graphic imaging technology in the infrared irradiation range makes it possible to know directly and accurately the surface temperature distribution, whether in the environment or in the birds.

At the end of the creation, what begins to influence is no longer the metabolism, but 
the competition for space. In both aviaries the movement in the final phase of fattening, is compromised by the lack of space harming the abilities of heat dissipation. According to Vale et al. (2016), birds try to compensate for their reduced ability to dissipate latent heat under conditions of thermal stress, activating the physiological and behavioral processes responsible for the dissipation of heat to the external environment, keeping the wings away from the body, increasing its area of body surface, facilitating losses by convection.

The thermo graphic analysis is the inspection technique performed using infrared systems, for the measurement of temperatures or observation of differential heat distribution patterns, in order to provide information on the operational condition of a component, equipment or process (SINHA; SASTRY; GUPTA, 2016). This analysis can be performed by thermal imaging obtained from an infrared thermal, which is a safe, non-invasive and non-destructive technique and, in this case, does not interfere with the routine of the animal (SINHA; SASTRY; GUPTA, 2017).

The evaluation of measurement errors is important for the accuracy of the thermo graphic service, which can be classified as method, calibration and electronic errors. In real conditions, the measurement errors may, according to Kirollos, (2017) occur due to: incorrect evaluation of the emissivity of the object, atmospheric temperature, ambient temperature and the distance between the object and the chamber; influence of the radiation (direct or reflected by the object) arriving at the camera detector or incorrect evaluation of the transmission and atmospheric radiation. The emissivity depends on the wavelength, the temperature, the material, and the state of the surface and the direction of the observation. The influence of the radiation emitted by the environment increases when the emissivity decreases. The influence of the sun's radiation on the accuracy of the term spelling is quite difficult to evaluate, since the vicinity of the object can cover different values of emissivity.

Thus, the objective of this research was to evaluate the thermal influence of the white and blue colors of the sanitary curtain used as lateral closures in commercial broiler chickens, aiming the welfare and environment suitable for the production of broilers and if the infrared thermography is a suitable tool for non-invasively thermal evaluation of the animals in their accommodation .

\section{MATERIAL AND METHODS}

In order to carry out this study, we used images collected in two aviaries in a commercial farm of Cobb Ventres broilers in the city of Rio Claro, located in the Center-East of the state of São Paulo, coordinates $22^{\circ} 05^{\prime}$ and $22^{\circ} 40$ 'S, $47^{\circ} 30^{\prime}$ and $47^{\circ} 55^{\prime} \mathrm{W}$ and altitude of $613 \mathrm{~m}$, tropical climate with prevailing SE winds, average winter temperature of $20.3^{\circ} \mathrm{C}$. The data were obtained at the Main Climatological Station belonging to the National Institute of Meteorology (INMET) station São Paulo (IAG), SP. The aviaries consisted of housing for broilers arranged side by side at a distance of $30 \mathrm{~m}$ between each other, with the same dimensions and constructive characteristics and east-west orientation (Figure 1). 
Figure 1 - Distribution of housing constructions for broilers

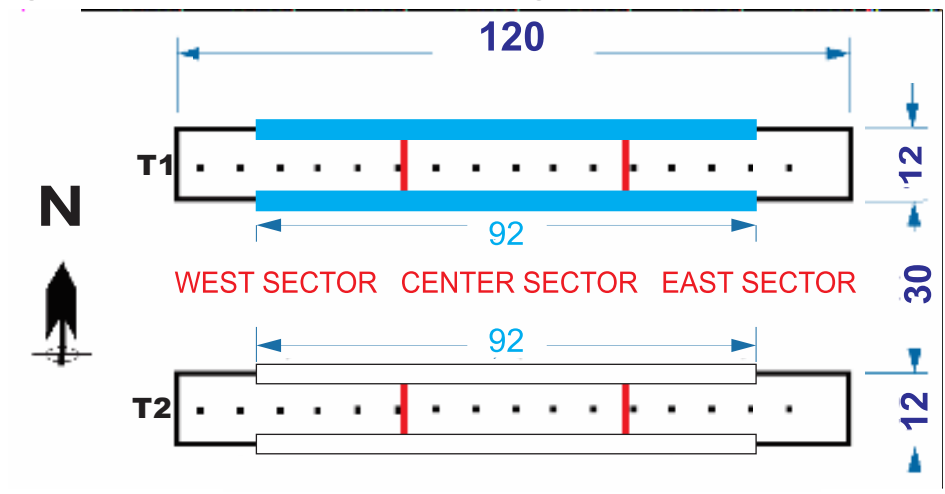

Caption: T1 blue lateral sanitary curtain and T2 white lateral sanitary curtain, both measuring 92 meters.

Source: The Authors.

\section{CHARACTERISTICS OF HOUSING FOR BROILERS}

The aviary ventilation system has 12 negative pressure fans, each with 1.5 hp motors, where the air is sucked from the inside out, establishing a partial vacuum inside the building.

Both sheds are $12 \mathrm{~m}$ wide by $120 \mathrm{~m}$ long, with $3.0 \mathrm{~m}$ ceilings and concrete pillars every 8 $\mathrm{m}$, with wood shears and fiber cement roof (Figure 1 ). In aviaries the air is cooled to the entrance where they are arranged and plates cooling that use 32,6 meters, with 2 motors of 0,75 CV in each aviary.

The side curtain used to seal the aviary T1 is a blue color with 92 meters long by 3 meters high, internally and externally, with inner lining used as thermal insulation. In the aviary $\mathrm{T} 2$, the lateral curtain was made of non-laminated polypropylene material, thickness $0.18 \mathrm{~mm}$, white color and emissivity 0.87 . The inner and outer color of this curtain is white with 92 meters long by 3 meters high and the inner lining, used as thermal insulation, were both non-laminated polypropylene material, thickness $0.17 \mathrm{~mm}$ and emissivity 0.95 . The chicken bed of the two aviaries followed a commercial recommendation consisting of shavings mixed with rice straw in the proportion of 50\% each. The birds were evaluated at the age of 14, 21, 35 and 42 days.

\section{COLLECTION OF TEMPERATURE DATA}

The data collection of superficial temperatures was carried out in the two aviaries by the recording of panoramic thermo graphic images, captured in four stages, from May to July, which characterize the winter in the southeast region of São Paulo state, at the time of 15h, characterizing the end of the warmer period of the day (BAÊTA; SOUZA, 2010).

With the help of the TESTO $^{\circledR}$ thermo graphic camera, model $8751 \mathrm{i}$ infrared images were taken in the center of the aviary, collecting superficial temperatures of the environment with birds at the age of 14, 21, 35 and 42 days, according to Baeta and Souza (2010), represent a breeding cycle for cutting birds. In the evaluation of the thermo graphic images were taken 20 random points in the images recorded by environment. Image processing used TESTO IR Soft ${ }^{\circledR}$ software to extract surface temperature values and set the average temperature of each image (figure 2 ). 
Figure 2 - Climatic data from May to July Data collection took place from May to July 2012

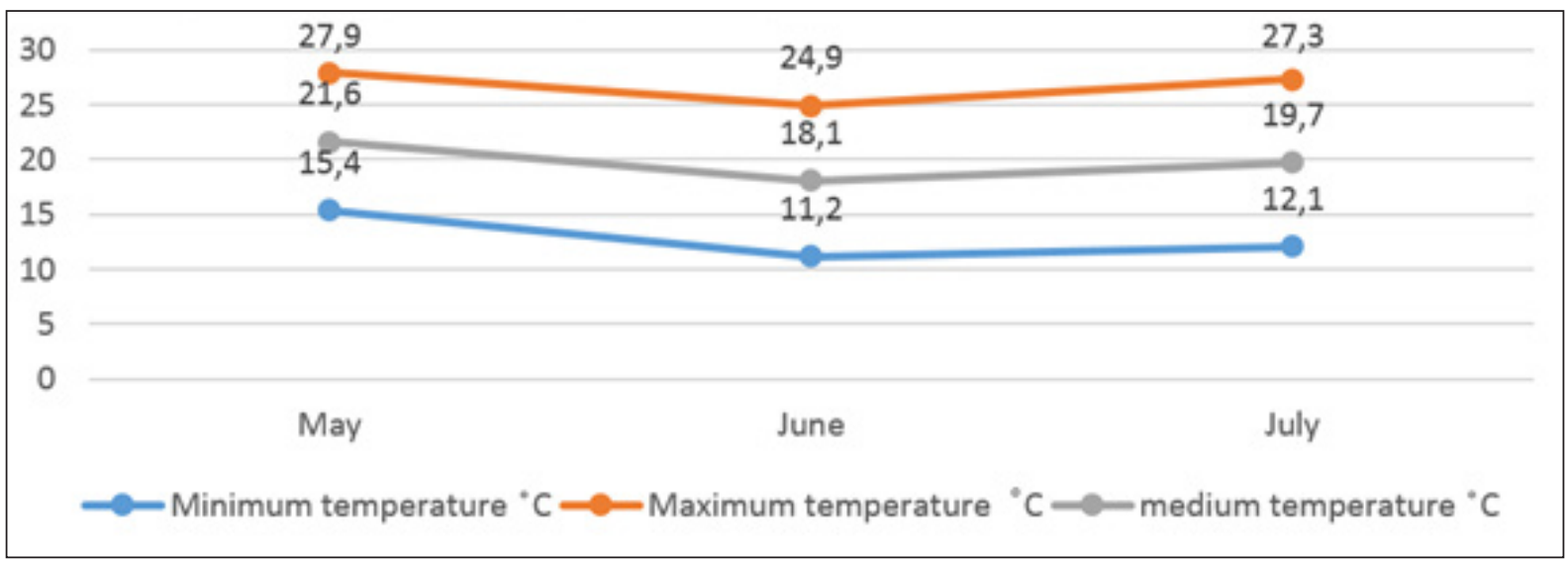

Source: The Authors:

\section{STATISTICAL TREATMENT OF DATA}

The collected temperature data were tabulated in worksheets compatible with the Excel ${ }^{\circledR}$ application. The Mean Surface Temperature (SST) data of infrared thermography were compared by Student's t test, with 95\% confidence, according to Curi et al. (2017).

\section{RESULTS AND DISCUSSION}

The production of birds in high density requires greater environmental thermal comfort. Thus, in order to remain competitive, the Brazilian poultry industry must rapidly evolve from a situation of almost indifference to the principles of conditioning the thermal environment, to a situation in which each company or integration must make decisions regarding the adoption of architectural conceptions and management innovative, associated with natural and artificial thermal conditioning systems compatible with their reality. These decisions include the upgrading of existing sheds and the design of new units (VALE et al., 2016).

The article explores this issue by addressing a methodology for assessing thermal comfort by infrared temperature measurements, as shown in Figure 3. 
Figure 3 - Internal appearance of the aviary endowed with blue and white sanitary curtain and color scale related to the measured temperature
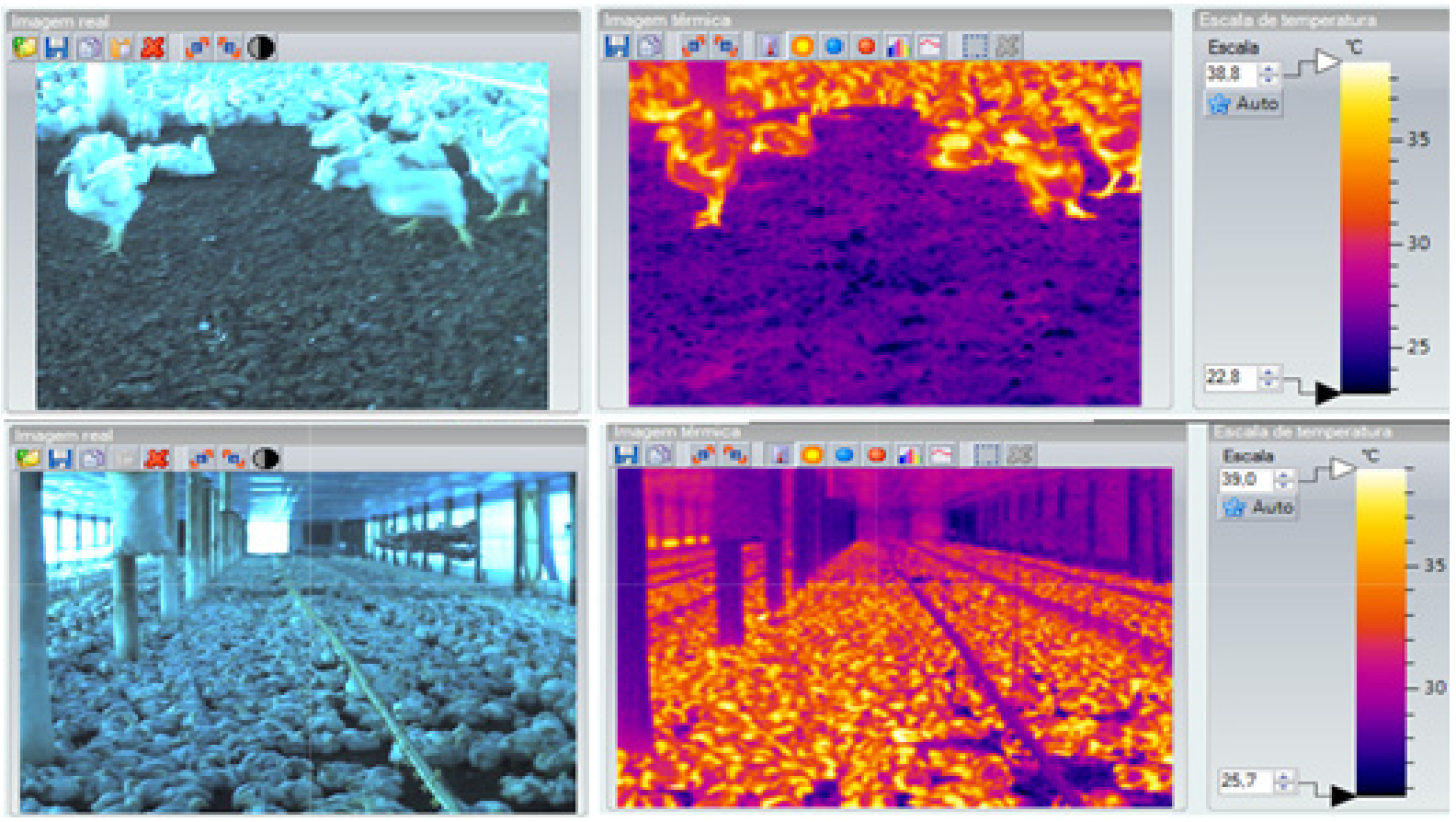

Source: The Authors:

The temperature measurements obtained with this methodology are shown in Table 1, and it is possible to see that inside the aviaries the average temperature ranged from 27.4 to 35.5 $\mathrm{C}$, higher than the internal temperatures of the aviaries. The highest temperatures were recorded in the first week, with $31.9{ }^{\circ} \mathrm{C}$ in the aviary with blue curtain, while aviary with white curtain, was $35.5^{\circ} \mathrm{C}$, (Table 1), as a reflection of the heating phase through which the birds passed. From the second week the recorded air temperature was lower and ranged from 25.5 to $26.1^{\circ} \mathrm{C}$ in the two aviaries.

Table 1 - Mean temperature in the center of two poultry aviaries, with blue and white sanitary curtains, located in Rio Claro, SP, data collected from May to June (average of 20 samples)

\begin{tabular}{ccc}
\multicolumn{3}{c}{ Average temperature in the center of the aviary $\left({ }^{\circ} \mathrm{C}\right)$} \\
\hline \multicolumn{3}{c}{ Color of sanitary curtain } \\
\hline Day / month / season & Blue & White \\
\hline 14/ May / Autumn & $31,9 \mathrm{aA}$ & $35,5 \mathrm{aA}$ \\
21/ June / Winter & $30,2 \mathrm{aB}$ & $27,4 \mathrm{bB}$ \\
35/ June / Winter & $28,0 \mathrm{aC}$ & $27,5 \mathrm{aB}$ \\
42/ July / Winter & $30,5 \mathrm{aAB}$ & $28,0 \mathrm{bB}$ \\
\hline
\end{tabular}

Caption: uppercase letters (column) and lowercase (line) differ the temperatures at the $95 \%$ level of confidence by the t-Student test 14, 21, 35 and 42 days.

Source: The Authors.

The results are in agreement with Freitas et al. (2017) using the same birds in similar place in the winter period. In the two aviaries, there was no need for warm-up, and birds in the growth phase did not present thermal stress (BAETA, 2010). Comparing the temperatures of Table 1 , 
it was noticed that there were temperature differences only in the first week, in relation to the color of the curtains, and the blue curtain provided a lower temperature. In the following weeks, already in the middle of winter, the shed with white curtain registered the lowest temperatures.

While temperatures ranged from May to June, averaging $31.9^{\circ} \mathrm{C}$ in the aviary with a blue curtain door in the aviary with a white curtain, these averages were higher at 32.5ㅇ. $\mathrm{C}$. From the second week the temperature decreased significantly, registering a variation between 25.5 and $26.1^{\circ} \mathrm{C}$. During this period, the average temperatures of the Rio Claro region were between 20.0 and $25.6 \circ \mathrm{C}$.

The results found in this research are in agreement with Freitas et al. (2017), who concluded that the two ventilation systems studied in commercial breeding sheds of tunnel-type broilers and lateral ventilation, were efficient to maintain the birds in conditions of thermal comfort. In Table 2 it is possible to verify the climatic conditions during the installation of the experiment in the period of four weeks with ages of $14,21,35$ and 42 days, respectively alternating.

The mean values of temperature during the experiment ranged from 27.4 to 35.5 으, and the maximum values were reached between the ages of 14 and 21 days, the minimum between 21 and 35 days. Winter conditions, with low temperatures and lower sunshine than the summer period, justifying the temperatures found, due to the color of the curtain, in the studies of Freitas (2017), similar values of temperature were found in the same type of research.

The highest temperature for the aviary equipped with white sanitary curtain occurred in May, when the chickens had 7 to 14 days after birth. Although there is influence of the local climate the animals also generate heat. According to Cecchin (2016), the metabolism of growing chicken directly influences the temperature of the environment, supported by studies confirming the effect of chick age on avian temperature (FREITAS et al., 2017; TAHAMTANI et al., 2016). Nevertheless, for Freitas (2017), the greatest influence is on environmental factors, as evidenced by Mohammadalipour et al. (2017) and Santos et al. (2016).

The temperature in the environment in which there was blue sanitary curtain presented variation. At the age of 35 and 42 days the environment presented a temperature around 28.0은 for a white color curtain, while at the age of 35 days it was around 270 (Figure 3) showing that the chicken from the 20 days is found at its highest metabolic rate, consuming a larger amount of feed and thus producing more heat (HAQUE et al., 2016).

When comparing the color of the curtains (Table 1), few changes were observed, with significant results at the ages of 21 and 35 days where the white curtain had the lowest temperature. However, it is possible to observe the lower temperatures at the ages of 21 and 35 days for white coloration, showing at this time, this being more efficient. In his research, Freitas, (2017) found that the white curtain presented lower values of surface temperature, confirming the values found in this study.

\section{CONCLUSION}

At the end of 42 days the white curtain represented the best mean surface temperature if evaluated without supplementary ventilation. It was also possible to conclude that the white color curtain was more efficient to maintain the well-being inside the aviary, especially in the sixth week of production. This study showed that infrared thermography is an interesting, noninvasive and recommended tool for the determination of temperature in aviaries, with a view to evaluating the behavior, which may reflect in the thermal comfort and well-being of the birds. 


\section{REFERENCES}

ASSOCIAÇÃO BRASILEIRA DE PROTEÍNA ANIMAL (ABPA). Chicken meat production totals 13.146 million tons in 2015. São Paulo: ABPA, 2015. Available in: http://abpa-br.com.br/noticia/producao-de-carne-defrango-totaliza-13146-milhoes-de-toneladas-em-2015-1545. Access in: 11 Nov. 2017.

BAÊTA, F. C.; SOUZA, C. F. Ambience in rural buildings: animal comfort. Viçosa: UFV, 2010. 246p.

BOCCARDI, S.; CARLOMAGNO, G. M.; SIMEOLI, G.; RUSSO, P.; MEOLA, C. Evaluation of impact-affected areas of glass fibre thermoplastic composites from thermo graphic images. Measurement Science and Technology, v. 27, n. 7, 2016.

BRAZILIAN INSTITUTE OF GEOGRAPHY AND STATISTICS (IBGE). Relators 2017. Available in: https://www. ibge.gov.br/estatisticas-novoportal/economicas/agricultura-e-pecuaria/9203-pesquisas-trimestrais-doabate-de-animais.html?=\&t=downloads. Access in: 27 Nov. 2017.

CECCHIN, D.; CAMPOS, A. T.; SCHIASSI, L.; DA CRUZ, V. M. F.; SOUSA, F. A. Fuzzy index for the thermal comfort of pigs in the growth and finishing phase based on surface temperature and respiratory rate. Energy in agriculture. Energy in Agriculture, v. 31, n. 4, p. 334-41, 2016.

CURI, T. M. R. D. C.; CONTI, D.; VERCELLINO, R. D. A.; MASSARI, J. M.; MOURA, D. J. D.; SOUZA, Z. M. D.; MONTANARI, R. Positioning of sensors for control of ventilation systems in broiler houses: a case study. Scientia Agricola, v. 74, n. 2, p. 101-9, 2017.

FREITAS, L. C. S. R.; TINÔCO, I. F. F.; BAÊTA, F. C.; BARBARI, M.; CONTI, L.; JÚNIOR, C. T.; SOUSA, F. C. Correlation between egg quality parameters, housing thermal conditions and age of laying hens. Agronomy Research, v. 15, n. 3, p. 687-93, 2017.

HAQUE, N.; SINGH, M.; HOSSAIN, S. A. Up-regulation of milk secretion with modified microclimate through manipulating plasminogen-plasmin system in Murrah buffaloes during hot dry season. International journal of biometeorology, v. 60, n. 12, p. 1819-28, 2016.

KIROLLOS, B.; POVEY, T. High-accuracy infra-red thermography method using reflective marker arrays. Measurement Science and Technology, v. 28, n. 9, p. 095405, 2017.

MOHAMMADALIPOUR, R.; RAHMANI, H. R.; JAHANIAN, R.; RIASI, A; NILI, N. Effect of early feed restriction on physiological responses, performance and ascites incidence in broiler chickens raised in normal or cold environment. Animal, v. 11, n. 2, p. 219-26, 2017.

RAJAEI-SHARIFABADI, H.; GREENE, E.; PIEKARSKI, A.; FALCON, D.; ELLESTAD, L.; DONOGHUE, A.; DRIDI, S. Surface wetting strategy prevents acute heat exposure-induced alterations of hypothalamic stress-and metabolic-related genes in broiler chickens. Journal of Animal Science, v. 95, n. 3, p. 1132-43, 2017.

RAMOS, M. J. M.; VITAL, A. R. Survey of production system, problems and demands of agriculture of the state of Mato Grosso by the rapid survey. Brazilian Journal of Sustainable Agriculture, v. 6, n. 1, 2016.

RODRIGUES, A; BORGES, E. N.; BARWALDT, R. A study on the broiler feed behavior using data mining. Scientia Plena, v. 13, n. 4, 2017.

SANTOS, R. C.; ÁVALO, H.; NÄÄS, I. A.; GEISENHOFF, L. O. SILVA, N. C. Uso da termografia infravermelha na avaliação ambiental de aviários. Ambiência e engenharia na produção sustentável: condições de clima quente e temperado. Viçosa: SUPREMA, 2016. p. 577-87. v. 1. 
SEKHAR, S. C. Thermal comfort in air-conditioned buildings in hot and humid climates-why are we not getting it right? Indoor Air, v. 26, n. 1, p. 138-52, 2016.

SINHA, A; SASTRY, O. S.; GUPTA, R. Nondestructive characterization of encapsulant discoloration effects in crystalline-silicon PV modules. Solar Energy Materials and Solar Cells, v. 155, p. 234-42, 2016.

TAHAMTANI, F. M.; NORDGREEN, J.; BRANTSAETER, M.; ØSTBY, G. C.; NORDQUIST, R. E.; JANCZAK, A. M. Does early environmental complexity influence Tyrosine hydroxylase in the chicken hippocampus and "Prefrontal" caudolateral nidopallium? Frontiers in veterinary science, v. 3, 2016.

VALE, M. M. D.; MOURA, D. J. D.; NÄÄS, I. D. A.; CURI, T. M.; LIMA, K. A. Effect of a simulated heat wave in thermal and aerial environment broiler-rearing environment. Engenharia Agrícola, v. 36, n. 2, p. $271-$ $80,2016$.

ZHU, S.; PICKLES, J.; HE, C. Geographical Dynamics and Firm Spatial Strategy in China. Springer, 2017.

\section{About the authors:}

Helio Ávalo: Master's degree in Agricultural Engineering from the Universidade Federal da Grande Dourados. Expert on Methodology of Higher Education from the Instituto de Estudos Avançados e Pós-Graduação. Graduated in Business Administration from the Faculdade de Administração de Nova Andradina. With experience in administration area, acting in the following topics: Business Consulting, Distance Learning Courses (EaD), Free Courses, Corporate Universities, development of projects and lectures. E-mail: helioavalo@hotmail.com, Orcid: http://orcid.org/0000-0002-7278-1665

Rodrigo Couto Santos: Doctorate, master's and graduate degree in Agricultural Engineering. Professor at the Universidade Federal da Grande Dourados (UFGD). E-mail: rodrigoambiencia@gmail.com, Orcid: http://orcid.org/0000-0003-4585-9305

Marney Pascoli Cereda: Postdoctoral in Spain, France and England. Graduated in Agronomy. Full professor at the Universidade Católica Dom Bosco (UCDB). E-mail: cereda@ucdb.br, Orcid: http://orcid.org/0000-0002-8181-7754

Glaucia Almeida de Morais: Doctorate in Biological Sciences from Universidade Estadual Paulista (UNESP). Professor at the Universidade Estadual de Mato Grosso do Sul (UEMS). Acts in Botany, Ecophysiology, Environmental Education and Recovery of Degraded Areas. E-mail: glaumorais1@gmail.com, Orcid: http://orcid.org/0000-0002-6498-8164 
